\title{
Parasitic infections of the European brown hare (Lepus europaeus Pallas, 1778) in south -western Slovakia
}

\author{
P. DUBINSKÝ ${ }^{1}, Z_{\text {. VASILKOVÁ }}{ }^{*}$, Z. HURNÍKOVÁ $^{1}$, M. MITERPÁKOVÁ $^{1}$, J. SLAMEČKA $^{2}$, R. JURČÍK ${ }^{2}$ \\ ${ }^{1}$ Parasitological Institute of Slovak Academy of Sciences, Košice, Slovak Republic, E-mail: vasilko@saske.sk \\ ${ }^{2}$ Animal Production Research Centre Nitra, Department of Small Farm Animals, Lužianky, Slovak Republic
}

\begin{abstract}
Summary
A total of 74 European brown hares (Lepus europaeus Pallas, 1778), hunted during the winter seasons of 2006 and 2007, were examined by dissection for the presence of helminths and coprologically for protozoa. The animals came from five districts with a high population density of this species. Our results revealed $54.5 \%$ of specimens being infected with one or more helminth species and a high prevalence of eimeriid coccidia $(91.89 \%)$. The most prevalent helminth species was Trichuris leporis (55.41\%). Lower prevalence was found for Passalurus ambiguus $(12.16 \%)$ and Trichostrongylus retortaeformis $(6.76 \%)$. The intensity of infection was low for all parasite species. As for coccidia, Eimeria semisculpta (74.35\%) and $E$. leporis $(61.54 \%)$ were recorded in all districts. Other coccidia showed lower prevalence rates: E. robertsoni (15.38\%), E. europaea (12.82\%), E. babatica (12.82\%), E. hungarica $(5.13 \%)$ and $E$. towsendi $(2.56 \%)$, occurring only in some districts. The highest infection rate was observed in E. semisculpta, 7657.8 oocysts per gram of faeces $(\mathrm{OPG})$. The potential effect of protozoan infection on hare mortality is discussed.
\end{abstract}

Keywords: hares; eimeriid coccidia; helminths; Slovakia

\section{Introduction}

European brown hare Lepus europaeus Pallas, 1778 is an important part of the wildlife fauna. This typical inhabitant of agrarian landscapes prefers agricultural land in the southwest and southeast of Slovakia, where the population is the most abundant. Hare numbers were high until 1974; annually up to 354000 animals were hunted. In the 1970's a steep decline in the hare population was recorded and in 1982 only $10 \%$ of the above number was hunted. In the following years, the population dynamics was unstable and hare harvest was very low (Slamečka et al., 1997). A similar decreasing trend in hare numbers has been noted throughout Europe for the past thirty years (Marboutin et al., 2003). There are many probable reasons for fluctuations in the hare population in Europe; however, deterioration of animal health strongly influenced by anthropization of landscape seems to be the key factor.

Hares suffer considerably from predation, particularly by foxes (Newey et al., 2007; Romig et al., 2007; Di Cerbo et al., 2008; Miterpáková et al., 2009), and the decline was accompanied by a growth in predators in recent years. The population density may also be influenced by different diseases, some of them occurring only locally. Parasitic diseases are also considered to be a regulative factor of hare population (Alzaga et al., 2009).

The parasitostatus in European brown hare in Slovakia and neighbouring countries was surveyed particularly in the 50 's and 60's of the last century and the results are summarised by Nickel and Gottwald (1979). The authors indicate a diverse species composition of protozoa and helminths. In the first group, Eimeria semisculpta, E. europea and E. leporis predominated. In localities with endemic occurrence of Fasciola hepatica and Dicrocelium dendriticum these helminths were sporadically also found in the gall bladder and common bile ducts of hares. In the intestines adult tapeworms were observed sporadically, with Mosgovoya pectinata being the most prevalent species. Out of other helminth species infecting the digestive tract, Graphidium strigosum in stomach, Trichostrongylus retortaeformis, Trichuris leporis and Passalurus ambiguus in intestines were most frequent. The most pathogenic species are G. strigosum in the stomach and Protostrongylus commutatus in the lungs (Kotrlá, 1984).

The records on the parasitic status of the European brown hare in Europe include a wide spectrum of parasitic species. Soveri and Valtonen (1983) found 2 coccidian and 3 helminth species in Finland, whereas Allgöwer (1992) detected 6 coccidian and 5 helminth taxa in SchleswigHolstein. Pakandl (1990) referred to the occurrence of 9 
coccidian species in different parts of the former Czechoslovakia with the prevalence in hares ranging from $1.3 \%$ up to $74.8 \%$. Aoutil et al. (2005) recorded infestation with new eimeriid coccidia species in hares from France. Lungmayr et al. (2008) found parasites (both helminths and protozoa) in $100 \%$ of hares originating from Belgium and Austria.

In Slovakia, as well as in the former Czechoslovakia, the parasitostatus of hare was very similar to those in neighbouring countries 50 years ago. Ryšavý (1954) referred to the presence of 8 eimeriid coccidia species; Kotrlá (1984) mentioned 7 most prevalent of them. Dobšinský (1955) found 5 helminth taxa in the area of eastern Slovakia. Ašmera et al. (1965) detected 5 species of eimeriid coccidia and 6 helminth taxa in hares from northern Moravia. In the areas of the Tatras National Park, Mituch (1970) identified 8 helminth species. The data on parasitic fauna composition obtained by coprological examination of hares from the area of south-western Slovakia (Jurčík et al., 1995, 2007) revealed a high prevalence of coccidiosis caused by 8 species. The oocysts of Eimeria semisculpta were the most frequent $(89.3 \%)$ and other species were present in one third of samples. The longterm high prevalence rates of Trichostrongylus spp. and Trichuris leporis spp. recorded were also surprising. This paper describes the infestation with helminths detected by means of stomach and intestines dissection and quantitative occurrence of coccidian oocysts in faeces of brown hares hunted within two winter seasons in five south-western districts of Slovakia.

\section{Material and Methods}

A total of 74 European brown hares were shot in seven sites of five districts (Trnava, Senec, Galanta, Šal'a and Dunajská Streda) during the winter seasons of 2006/2007 and $2007 / 2008$. The eye lenses were removed in order to estimate their age (Hell, 1972). The eyeball was removed with blunt scissors, placed into a sample case with $4 \%$ formaldehyde and allowed to fix for 14 days. The isolated lenses were then placed on a watch glass dried in $110^{\circ} \mathrm{C}$ for 24 hours and weighed. According to the age, hares were divided into two groups: the young and sub-adult hares, and the adults. The population dynamics in individual years were evaluated according to the proportion of young animals in game bags as a percentage of the reproduction coefficient $\mathrm{R}$ (the ratio of young animals per adults), and the reproduction factor $r$ (the number of young hares per adult female) (Slamečka et al., 1997). The stomach and intestines were removed from all 74 hares, and the liver and lungs from six of them. The organs were then stored at $-20{ }^{\circ} \mathrm{C}$ until examination. Following dissection, helminths were counted and fixed in $70 \%$ ethanol, or Barbagal solution.

Two grams of faecal samples were removed from the rectum, mixed with $15 \mathrm{ml}$ of $2.5 \%$ potassium dichromate solution and left for sporulation at a room temperature. Eimeria species were determined according to Černá (1983), Pakandl (1990) and Aoutil (2005). The number of oocysts per gram of faeces (OPG) was defined by the quantitative McMaster technique as described in the Manual of Veterinary Parasitology Techniques (Anonymous, 1986).

Differences in prevalence and intensity of infection were determined using Chi-square tests. Values were considered significant at $P<0.05$.

\section{Results}

The results of the dissection, coprological examinations and data on the presence of endoparasites in hares are given in Table 1. As much as $57.1 \%$ of the animals were juveniles and sub-adults, with females comprising $76.5 \%$. The data refer to a high occurrence of endoparasites in the digestive system, as the prevalence rates reached $100 \%$ in several localities. The differences in hare infestation were not

Table 1. Parasitostatus of Lepus europaeus in south-western Slovakia in 2006 and 2007

\begin{tabular}{lllccccc}
\hline \multirow{2}{*}{ District } & Locality & Year & $\begin{array}{c}\text { No. } \\
\text { of examined }\end{array}$ & \multicolumn{2}{c}{$\begin{array}{c}\text { Protozoa } \\
\text { Infected } \\
\text { Prevalence (\%) }\end{array}$} & \multicolumn{2}{c}{$\begin{array}{c}\text { Helminths } \\
\text { Infected }\end{array}$} \\
Prevalence (\%)
\end{tabular}




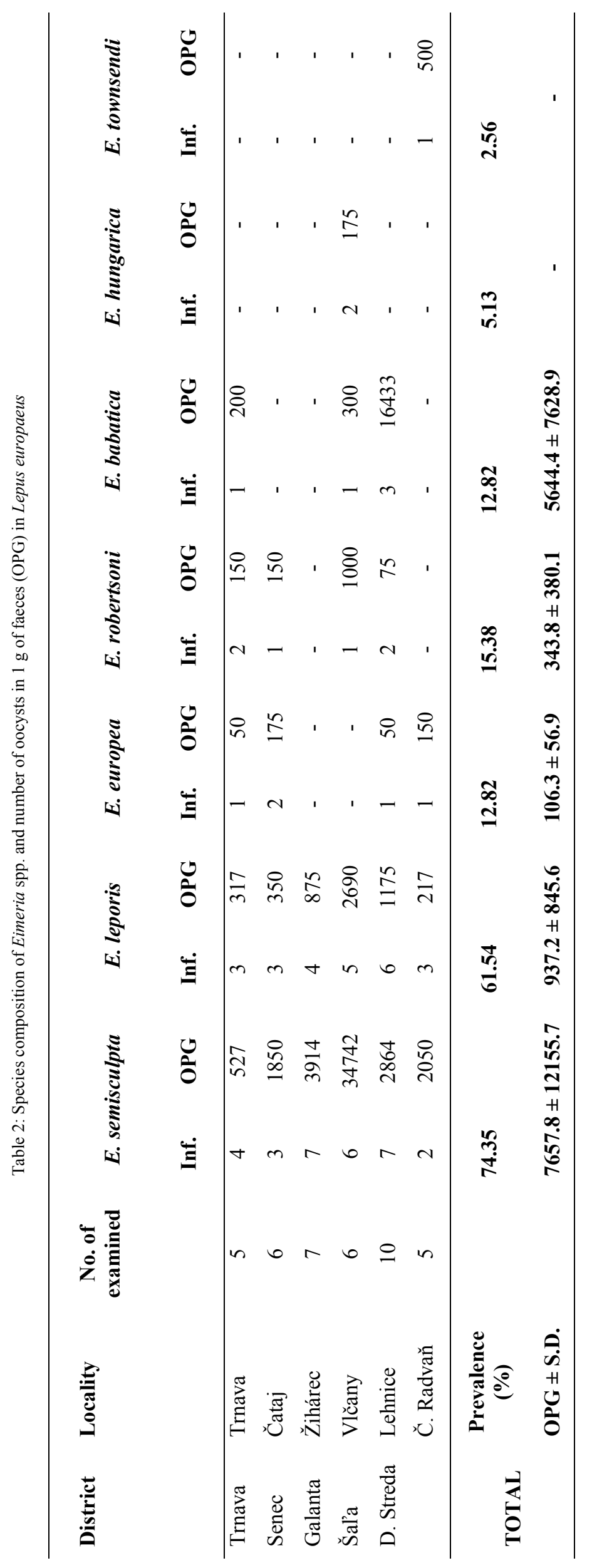


Table 3. Helminth species composition in Lepus europaeus

\begin{tabular}{|c|c|c|c|c|c|c|c|c|c|}
\hline \multirow{2}{*}{ District } & \multirow{2}{*}{ Locality } & \multirow{2}{*}{ Year } & \multirow{2}{*}{$\begin{array}{c}\text { No. } \\
\text { of examined }\end{array}$} & \multicolumn{2}{|c|}{ Trichuris leporis } & \multicolumn{2}{|c|}{$\begin{array}{c}\text { Trichostrongylus } \\
\text { retortaeformis }\end{array}$} & \multicolumn{2}{|c|}{ Passalurus ambiguus } \\
\hline & & & & Infected & $\begin{array}{c}\text { Prevalence } \\
(\%)\end{array}$ & Infected & $\begin{array}{c}\text { Prevalence } \\
\qquad(\%)\end{array}$ & Infected & $\begin{array}{c}\text { Prevalence } \\
(\%)\end{array}$ \\
\hline \multirow[t]{2}{*}{ Trnava } & Trnava & 2006 & 9 & 5 & 55.56 & - & - & - & - \\
\hline & & 2007 & 5 & 1 & 20.0 & - & - & 1 & 20.0 \\
\hline Senec & Čataj & 2007 & 6 & 1 & 16.67 & - & - & 2 & 33.3 \\
\hline \multirow[t]{2}{*}{ Galanta } & Žihárec & 2006 & 7 & 3 & 42.86 & 3 & 42.86 & 2 & 28.57 \\
\hline & & 2007 & 7 & 4 & 57.14 & - & - & 1 & 14.29 \\
\hline \multirow[t]{2}{*}{ Šal'a } & Diakovce & 2006 & 6 & 4 & 66.67 & - & - & - & - \\
\hline & Vlčany & 2007 & 6 & 6 & 100.0 & - & - & 2 & 33.3 \\
\hline \multirow[t]{5}{*}{ D. Streda } & Lehnice & 2006 & 9 & 5 & 55.56 & 2 & 22.2 & 1 & 11.1 \\
\hline & & 2007 & 10 & 5 & 50.0 & - & - & - & - \\
\hline & Č. Radvan̆ & 2006 & 4 & - & - & - & - & - & - \\
\hline & & 2007 & 5 & 3 & 60.0 & - & - & - & - \\
\hline & & 2006 & 35 & 21 & 60.0 & 5 & 14.29 & 3 & 8.57 \\
\hline \multirow[t]{2}{*}{ TOTAL } & & 2007 & 39 & 20 & 51.28 & - & - & 6 & 15.38 \\
\hline & & $2006-2007$ & 74 & 41 & 55.41 & 5 & 6.76 & 9 & 12.16 \\
\hline
\end{tabular}

significant between the two years. Eimeriid coccidia were the major parasites with the prevalence rate of $91.89 \%$. Helminths were detected in $54.05 \%$ of examined animals. In hunted hares, seven coccidia species were determined. Their composition, as well as oocysts output, varied greatly within the sites examined (Table 2). Hares from all localities harboured E. semisculpta, with the prevalence rate of $74.35 \%$ and the high OPG values of 7657.8 oocysts. E. leporis was detected in $61.54 \%$ of the animals, but the OPG value was only 937.2 oocysts. Other coccidian species were present only in $2.56-15.38 \%$ of the hares, either in the most of the districts (E. europea, E. robertsoni), or sporadically (E. babatica, E. hungarica and $E$. towsendi). Except for E. babatica, reaching as much as 16433 OPG in the locality of Lehnice, the mean OPG values were very low.

The helminth species composition of the digestive systems in hares was rather limited (Table 3). Trichuris leporis was the only species detected in all districts with the mean of $55.41 \%$ of infected specimens. The prevalence varied from $16.67 \%$ in the Čataj locality up to $100 \%$ in Vlčany locality. Out of 74 hares, only five animals $(6.76 \%)$ harboured Trichostrongylus retortaeformis. Passalurus ambiguus was present in nine hares $(12.16 \%)$. No significant difference was found in the numbers of infected individuals between years of examination. The helminth burden

Table 4. Change to the corellation between coccidia oocysts numbers and population growth of Lepus europaeus

\begin{tabular}{|c|c|c|c|c|c|c|}
\hline \multirow[t]{2}{*}{ District } & \multirow[t]{2}{*}{ Locality } & \multicolumn{3}{|c|}{ Indicator of hare population growth } & \multicolumn{2}{|c|}{$\begin{array}{c}\text { No. } \\
\text { of coccidia oocysts } \\
\text { (OPG) } \\
\end{array}$} \\
\hline & & $\begin{array}{c}\text { Proportion } \\
\text { of young animals } \\
(\%)\end{array}$ & $\begin{array}{l}\text { Reproduction } \\
\text { coeficient } \\
\quad \text { (R) }\end{array}$ & $\begin{array}{l}\text { Reproduction } \\
\text { factor } \\
\text { (r) }\end{array}$ & E. semisculpta & E. leporis \\
\hline Trnava & Trnava & 49.53 & 0.98 & 1.82 & 527 & 317 \\
\hline Senec & Čataj & 29.63 & 0.42 & 1.6 & 1850 & 350 \\
\hline Galanta & Žihárec & 38.64 & 0.62 & 1.0 & 3914 & 875 \\
\hline Šal'a & Vlčany & 12.50 & 0.14 & 0.22 & 34742 & 2690 \\
\hline \multirow[t]{2}{*}{ Dunajská Streda } & Lehnice & 20.0 & 0.26 & 0.55 & 2864 & 1175 \\
\hline & Čiližská Radvaň & 35.42 & 0.54 & 0.94 & 2050 & 217 \\
\hline \multirow{2}{*}{\multicolumn{2}{|c|}{$\begin{array}{l}\text { Corellation Coefficient }(r \pm) \\
\text { with OPG } E \text {. semisculpta } \\
\text { Corellation Coefficient ( } r \pm \text { ) } \\
\text { with OPG } E \text {. leporis }\end{array}$}} & -0.27 & -0.62 & -0.68 & & \\
\hline & & -0.79 & -0.70 & -0.81 & & \\
\hline
\end{tabular}


was low (1 to 3 specimens) in all positive animals and no patho-morphological changes related to infection were observed. All the lungs and livers examined had no helminths or their larval stages.

Evaluation of hares from six localities according to their age and gender enabled us to determine the hare population status and evaluate population growth in relation to the number of oocysts of the eimeriid coccidia species that were determined in all localities (Table 4). Only a weak negative correlation ( $r-0.62$, resp. $r-0.68)$ was observed among the number of E. semisculpta oocysts and reproduction coefficient or reproduction factor. However, a high negative correlation ( $r-0.70$ to $r-0.81)$ was found between the number of E. leporis oocysts and the indexes of population growth.

\section{Discussion}

The population of European brown hare has fluctuated regularly. According to Bakoš and Hell (1981), its population cycle lasts on an average from 10 to 12 years, with a distinct oscillating of the population growth curve both in its upper and lower levels, the most noticeable in a 3 to 6year intervals.

Partly due to different environmental conditions, the hare population in Slovakia is geographically unevenly distributed. In 2007, the highest spring stock numbers reached 73510 animals in the Nitra region and 63230 animals in the Trnava region, probably due to the existence of large farmland areas in this territory. In total, 28604 hares have been hunted this year in these regions, i.e. $89.9 \%$ of the national production. Per 100 ha, 5.3 animals were hunted in the Trnava region and 3.2 animals in the Nitra region. In the Košice region, it is as low as 0.3 animals per 100 ha, even though the farmland area covers $52.9 \%$ of the landscape. The population growth rates fluctuated rapidly, varying from $35.13 \%$ (expressed as percentage of yearlings in the game bags) in 2006 to $57.42 \%$ in 2007 (Slamečka \& Hell, 2009).

Fluctuation of the hare population has been attributed to many factors, in particular to climatic conditions in the relevant year, which greatly influence animal morbidity (Bakoš and Hell, 1981; Slamečka et al., 1997). Unlike other time- and area-limited infections, the agents of parasitic diseases occur permanently in the hare population. They negatively affect particularly animals already weakened by other factors. Leverets are especially vulnerable to several coccidia species that are highly pathogenic, the stomach damaging haematophagous helminth G. strigosum and the lungworm $P$. commutatus, which affects the parenchyma of the lungs, leading to secondary bacterial infections resulting in death (Sitko et al., 1970). However, no lungworms were detected in hares from our studied localities, similar to the data of Jurčík et al. (2007) during 2004 and 2005.

The present survey revealed high prevalence rates of eimeriid coccidia (91.89\%), whilst helminth prevalence was lower $(54.05 \%)$. Differences in prevalence rates be- tween years were insignificant. The data refer to long-term stable parasite prevalence in the hare population. Similar results were observed by other authors (Ašmera et al., 1965; Pakandl, 1990; Allgöwer, 1992; Jurčík et al., 2007).

High coccidia prevalence in hares has probably been due to the predominance of young and sub-adult animals $(57.1 \%)$ in the sampling. Two species, E. semisculpta and E. leporis, were detected in all localities with the high mean prevalence rates $(74.35 \%$ resp. $61.54 \%)$. Since young hares are particularly vulnerable to coccidian infections, we analyzed the correlation between the number of oocysts (OPG) and population dynamics in relevant hunting grounds. Our data showed that E. leporis has negatively affected the indexes of population growth, thus confirming that this species is more pathogenic than the other (Pellérdy et al., 1974; McCulloch et al., 2004). Our findings also confirm the correlation between the age and OPG, and thus potential pathogenicity of coccidia. The highest OPG values in E. semisculpta (34742 oocysts) and E. leporis (2690 oocysts) were recorded in Vlčany, where only young hares were examined. In the recent study from Poland, three Eimeria species reached the highest OPG - E. europea (18756 OPG), E. leporis (18381 OPG) and E. robertsoni (8294 OPG) (Pilarczyk et al., 2008).

Prevalence rates for other Eimeria species were low and they occurred in some localities only in isolated cases. Similar findings on variable occurrence of eimeriid coccidia in hares were also reported by other authors. Gottschalk (1973) recorded the highest prevalance of $E$. europaea (46.7 \%) in Germany; Gräfner et al. (1967) found in Germany near Schwerin the highest prevalence of E. semisculpta $(94.3 \%)$ and E. leporis $(50.0 \%)$ which is consistent with our results from Slovakia. A high prevalence of E. leporis was reported by Nickel and Gottwald (1979) near Dresden. Kutzer and Frey (1976) referred to a high prevalence of E. semisculpta $(52.1 \%)$ and E. leporis $(47.5 \%)$ in hares from Austria, but E. robertsoni were even more prevalent $(53.6 \%)$. The latest survey conducted in Austria reported seven coccidian species found in hares (E. semisculpta, E. robertsoni, E. leporis, E. europaea, E. septentrionalis, E. stefanskii and $E$. townsendi) (Lungmayr et al., 2008). Pakandl (1990) identified E. towsendi as predominant species $(67.1 \%-81.78 \%)$ in the Czech Republic during 1983 - 1985, while E. leporis and E. robertsoni were less prevalent. Böckeler et al. (1994) found $E$. semisculpta as the most frequent coccidia in hares from Schleswig-Holstein $(52.0 \%)$, E. leporis was less frequent $(29.0 \%)$ and $E$. robertsoni prevalence rates were similar $(15.0 \%)$ to those found in southern Slovakia (15.38\%).

Concerning the helminth fauna of hares, T. retortaeformis was the most prevalent species in Austria (Kutzer \& Frey, 1976), Poland (Czaplińska et al., 1965), Germany (Nickel \& Gottwald, 1979), and the Czech Republic (Ašmera et al., 1965). On the other hand, Pilarczyk et al. (2008), in the study performed in Poland, recorded low number of hares infected with this parasite species. Compared with $T$. leporis, lower prevalence of T. retortaeformis was reported also in Slovakia by Dobšinský (1955), Mituch (1970) 
and Kotrlá (1984). Our data confirm such records, as the $T$. leporis prevalence was higher $(55.41 \%)$ than that of $T$. retortaeformis $(6.76 \%)$, with an isolated occurrence in both districts.

Previous studies found a very low prevalence of $P$. ambiguus (Nickel \& Gottwald, 1979; Böckeler et al., 1994). Also Allgöwer (1992) found its prevalence to be $15 \%$ in hares from the Rhine region in Germany. Contrary to those data, Kotrlá (1984) stated $72 \%$ of hares infected with this species, however with low infection rates.

\section{Acknowledgement}

The study was supported by the Science Grant Agency VEGA projects No. 2/0145/09 and 2/0147/10.

\section{References}

AllGÖWER, R. (1992): Der Parasitenbefall von Feldhasen aus der Oberrheinebene und seine intraspezifische Bedeutung. Z. Jagdwiss., 38: 116 - 127. DOI: 10.1007/BF 02286501

Alzaga, V., Tizzani, P., Acevedo, P., Ruiz-Fons, F., VICENTE, J., GORTÁZAR, C. (2009): Deviance partitioning of host factor affecting parasitatization in the European brown hare (Lepus europaeus). Naturwissenschaften, 96: 1432 - 1904. DOI: 10.1007/s00114-009-0577-y

ANONYMOUS (1986): Manual of Veterinary Parasitological Techniques, Reference Book. Ministry of Agriculture, Fisheries and Food, Her Majesty's Stationary Office, London Aoutil, N., Bertani, S., Bordes, F., Snounou, G., Chabaud, A., LANDAU, I. (2005): Eimeria (Coccidia: Eimeridea) of hares in France: description of new taxa. Parasite, 12: $131-44$

AŠMerA, J., PejŠE, M., TOMÁNEK, J. (1965): On the epidemiological and epizootiological importance of European brown hare Lepus europaeus Pallas, 1778. Zool. Listy, 14: 98 - 106. (In Slovak with German summary)

BAKoš, A., Hell, P. (1981): Problems of leporine animal breeding. Pol'ov. rybárstvo, 33: 7. (In Slovak)

Böckeler, W., Mokhtari-Derakhshan, F. L., Pecher, W. T. (1994): On the parasitic infections of hares (Lepus europaeus) of Schleswig-Holstein. Z. Jagdwiss., 40: 22 29. DOI: $10.1007 / \mathrm{BF} 02241502$

CZAPlińsKA, D., CZAPliŃSKI, B., ŻEBROWSKA, D. (1965): Studies on the European hare. IX. Helminth fauna in the annual cycle. Acta Theriol., 10: 1

ČERNÁ, Ž. (1983): Coccidia of some pet and farm animals and human coccidia. Studie CSAV 3, Academia Praha. (In Czech)

Di Cerbo, A. R., Manfredi, M. T., Bregoli, M., Ferro, Milone, N., CovA, M. (2008): Wild carnivores as source of zoonotic helminths in north-eastern Italy. Helminthologia, 45: 13 - 19. DOI: 10.2478/s11687-008-0002-7

DOBŠINSKÝ, O. (1955): Contribution to knowledge of helminths from brown hares in the eastern part of Slovakia. Diploma thesis, University of Veterinary Medicine Košice. (In Slovak)
GotTschalK, C. (1973): Endoparasiten der Feldhasen in ihrer Rolle für die Niederwildjagd Ostthüringens. Angew. Parasitol., 14: 44 - 54

GrÄFner, G., Graubmann, H. D., Benda, A. (1967): Die Verbreitung und Bedeutung der Hasenkokzidiose im Bezirk Schwerin. Monatsh. Veterinarmed., 22: 449

HeLl, P. (1972): Hare and rabbit. Slovak publishing house for agricultural literature, Bratislava. (In Slovak)

JurČ́́K, R., Hell, P., SlameČKA, J. (1995): Der gesundheitliche Zustand des Feldhasen (Lepus europaeus) in der südwestslowakischen Agrarlandschaft. Säugetierkd. Inf., 4: 23 - 32. (In German)

JurČ́́K, R., SlameČKa, J., Mertin, D., Hell, P., GAŠPARÍK, J., MASSÁNYI, P. (2007): Actual health state of European brown hare from hunting grounds of south-western Slovakia. Folia Venatoria, 36 - 37: 89. (In Slovak)

Kotrlá, B. (1984): Parasitoses of wildlife animals. Academia, Praha. (In Czech)

Kutzer, E., Frey, H. (1976): Die Parasiten der Feldhasen (Lepus europaeus) in Österreich. Berl. Munch. Tierarztl. Wochenschr., 89: 480 - 492. (In German)

Lungmayr, Y., EISSNER, R., Duscher, G. (2008): Endoparasiten beim europänischen Feldhasen. In Parasitologische Fachgespräche 2008, 30 May, Innsbruck, Austria. Abstract book, pp. 15-17. (In German)

Marboutin, E., Bray, Y., Peroux, R., Mauvy, B., LARTIGES, A. (2003): Population dynamics in European hare: breeding parameters and sustainable harvest rates. $J$. Appl. Ecol., 40: 580 - 591. DOI: 10.1046/j.1365-2664.20 03.00813.x

MCCulloch, C. R., Prosl, H., SchMidT, P. (2004): A spontaneous and fatal jejunal intussusception in a European brown hare associated with Eimeria leporis. J. Vet. Med. B, 51: 470 - 472. DOI: 10.1111/j.1439-0450.2004. 00806.x

MiterpákovÁ, M., HuRníKOVÁ, Z., AntolovÁ, D., DUBINSKÝ, P. (2009): Endoparasites of red fox (Vulpes vulpes) in the Slovak Republic with the emphasis on zoonotic species Echinococcus multilocularis and Trichinella spp. Helminthologia, 46: 73 - 79. DOI: 10.2478/s116 87-009-0015-x

Mituch, J. (1970): Helminthfauna of small mammals and carnivores from the High Tatras National Park. Final report, Helminthological Institute of SAS. (In Slovak)

Newey, S., Dahl, F., Willebrand, T., Thirgood, S. (2007): Unstable dynamics and population limitation in mountain hares. Biol. Rev., 82: 527 - 549. DOI: 10.1111/j. 1469-185X.2007.00022.x

Nickel, S., GotTwald, A. (1979): Beiträge zur Parasitenfauna der DDR. 3. Mitteilung. Endoparasiten des Feldhasen (Lepus europaeus). Angew. Parasitol., 20: 57 - 62. (In German)

PAKANDL, M. (1990): Some remarks on the prevalence and species composition of hare coccidia. Folia Parasitol., 37 : $35-42$

Pellérdy, L., HöNiCh, M., SugÁR, L. (1974): Studies on the development of Eimeria leporis (Protozoa: Sporozoa) and on its pathogenicity for the hare (Lepus europaeus Pall.). Acta. Vet. Acad. Sci. Hung., 24: 163 - 175 
Pilarczyk, B., Balicka-Ramisz, A., Ramisz, A., CieCHANOWICZ J. (2008): Preliminary studies on parasitic fauna of hares introduced on the Chrzaszczewska Island, West Pomerania. Wiad. Parazytol., 54: 159 - 161. (In Polish)

Romig, T., Bilger, B., Dinkel, A., Merli, M., Thoma, D., Will, R., MackenstedT, U., Lucius, R. (2007): Impact of praziquantel baiting on intestinal helminths of foxes in southwestern Germany. Helminthologia, 44, 137 144. DOI: $10.2478 / \mathrm{s} 11687-007-0021-9$

RYŠAVÝ, B. (1954): Contribution to knowledge of native and imported vertebrate coccidia. Českoslov. Parazit., 1: 131 - 174. (In Czech)

RECEIVED DECEMBER 10, 2009
SitKo, M., Mituch, J., KonRad, V., ŠPeniK, M. (1970): The occurrence of protostrongylosis of hares and the patho-morphologic changes caused by it. Slov. Vet. Čas., 13: 163 - 167. (In Slovak)

SlAMEČKA, J., Hell, P., JURČÍK, R. (1997): Brown hare in the Westslovak Lowland. Acta Sci. Natur. Acad. Sci. Bohem. Brno, 31: 115

SlAMEČKA, J., Hell, P. (2009): Maintenance of hares in Slovakia. Svět Mysl., 10: 9. (In Slovak)

SOVERI, T., VALTONEN, M. (1983): Endoparasites of hares (Lepus timidus L. and L. europaeus Pallas) in Finland. J. Wildl. Dis., 19: 337 - 341

ACCEPTED SEPTEMBER 8, 2010 